\title{
The Effect of a Rehabilitation Program for Treating Chronic Muscle Pain Disease (Fibromyalgia) in Women
}

\author{
${ }^{1}$ Dr. Majed Muhammad Al-Ajarmah and ${ }^{2}$ Dr. Majed Fayez Majali \\ ${ }^{1}$ Occupational Therapist, Al-Basheer Hospital/ Ministry of Health, ${ }^{2}$ Associate Professor, The University of \\ Jordan
}

Abstract

The study sample included 9 women infected with the disease, their ages ranged between 40-55 years, and the following measures were used to examine the study variables: The McGill Pain Scale (MPQ), Fibromyalgia Overall Impact Scale (FIQ), anxiety and Depression Scale (HADS), muscle strength test for grip strength using dynamometer, CURLE-UP TEST for core muscles and SQUAT TEST for lower extremity muscles. The proposed program was applied to the study sample for a period of three months, with 3 sessions per week of physical therapy and two sessions per month of cognitive behavioral group therapy. Pre and post measurements were taken for the study sample. The results showed that there are statistically significant differences on each variable of pain, mental health and muscle strength in favor of the post measurement, and the absence of statistically significant differences on the quality of life, and the researcher concluded that the proposed program would be useful in relieving pain and improving the psychological state, and increase muscle strength in patients with fibromyalgia syndrome, these patients are recommended to adhere to the physical activities and exercises used in the program to alleviate their disease symptoms.

Keywords: Rehabilitation Program, Treating, Chronic Muscle Pain Disease (Fibromyalgia)

DOI: $10.7176 /$ JTHS/55-07

Publication date:March 31st 2021

\section{Introduction}

Fibromyalgia (FM) is a disease that affects the patient's life, especially as it is classified as a syndrome that impedes the life of the affected individual by causing an increase in the feeling of chronic muscle pain, general body fatigue, and disturbances in sleep, memory, and general mood, which calls for various therapeutic interventions (Salazar, 2017).

This syndrome is classified as a complex and difficult to understand condition that has a general effect that extends to all parts of the body, but its symptoms may be controlled and reduced despite the inability to get rid of them completely, and dealing with this syndrome is different from dealing with any other traditional disease, so that it can be treated with medicines and other therapeutic means such as physical and occupational therapy, yoga, Chinese needles, other mental and behavioral treatments, the use of relaxation methods and the adoption of healthy diets (Jordanian Association for Syndrome Chronic Muscle Pain, 2015).

Despite the widespread spread of this syndrome in various parts of the world, infecting millions of people with it, and the different degrees and locations of pain among patients, some doctors still believe that it is a fake syndrome, and that the infected persons pretend to be sick and they are people who suffer from laziness or have a state of insanity, or both, however, they are unfortunately wrong because the pain is not delusional and the symptoms are present and real and have been scientifically proven. It is worth noting that fibromyalgia is one of the diseases that affect women widely, with a ratio of one man to every seven or nine women and this is for unknown reasons, which affects the quality of their life and causes them various disorders (Hawkins, 2013) and (Bartels, 2009).

Despite the difficulty of this syndrome and its severe impact on the lives of affected patients, its symptoms can be controlled through several treatment methods, and this research deals with an important part of it, which is physical therapy through therapeutic exercises and occupational therapy through cognitive behavioral therapy concurrent with exercise, where therapeutic exercise is one of the most important physical therapy methods that relieve symptoms of the syndrome and control the various physical pain that the affected person feels, and continuing to practice these exercises leads to an improvement in the work of muscle motor units as a result of improved nerve signals and response to them in the muscle fibers targeted in the exercise, in addition to improving perfusion by increasing blood circulation activity and improving muscle flexibility by increasing its efficiency and ability to contract and relax. (Williams, 2003) and (Hauser et al., 2009).

\section{The problem and the importance of the study}

Through the researcher's work in the field of rehabilitation and her studies in the field of sports, the researcher noticed the presence of quite a few women with chronic muscle pain disease (fibromyalgia), and the researcher also noticed that these women are affected by this disease greatly, as it affects the quality of life they 
live in general due to the pain they are exposed to, especially when pressure is placed on specific areas of the body, and the state of fatigue and exhaustion that they live without justified reason and without physical effort deserves this fatigue, and that makes them less accomplished in their different jobs, whether they are workers or housewives or both. And the increased feeling of pain, fatigue and poor achievement is a reason to make them live in a bad mood and cause them to have a state of depression, And it is worth noting that the majority of those infected with this disease are women who believe that there is no cure for their disease and that there is no help provided to them, so many may refrain from seeking help, although there are many means that may provide health assistance to them and improve their quality of life, so they must realize that using these methods is their way to a better, healthy and qualitative life.

And the researcher believes, through her surveys, that most women with the disease believe that sports are physically strenuous and useless work, and they often move away from it to avoid feeling tired, consequently, they have low levels of physical fitness and their ability to cope with the symptoms of this disease whose cause is unknown, and they depend only on various types of medicines that cause annoying side effects such as dizziness, nausea, headache, etc.

The well-informed people should not lose sight of the great effects of continuing to take these drugs, specifically analgesics, on the human body and the emergence of many dangerous diseases as a result of the abuse of some types of medicines. The researcher also noticed that a good number of women are heading towards means of physical therapy and rehabilitation in general, and their belief in its ability to help them to alleviate the symptoms of the disease, but their approach to this treatment is random, not systematic or studied, due to the lack of special rehabilitation programs to treat this disease in hospitals or physical therapy centers, from here, the researcher saw the necessity to conduct a study that includes a codified program based on the use of physical therapy methods, especially sports exercises and means to complement them with the aim of helping patients without any negative complications on their bodies and providing them with the ability to use these methods on their own in various places.

Through the researcher's review and review of a number of libraries, especially electronic ones, the researcher noticed the scarcity of studies or studies in Arabic in the field of fibromyalgia, which is - from the researcher's point of view - an important area that affects the lives of a large number of women. And here lies the importance of this study.

It should be mentioned that this study - according to the researcher's knowledge - is the first of its kind in the Jordanian environment that uses physical education methods, sports and cognitive behavioral therapy, as these means are directed to serve a group of women who need help to improve their quality of life in general and alleviate the symptoms of this disease specifically by providing them with a comprehensive treatment program.

\section{The Objectives of the Study}

This study aimed to identify:

1. Identify the impact of the proposed and standardized training-sports program for treating chronic muscle pain (fibromyalgia) on the study variables (pain, muscle strength, mental health, and quality of life).

\section{Previous Studies}

Assumpcao, et al. (2017) conducted a study aimed at comparing the effectiveness of muscle stretching and resistance training exercises to relieve symptoms and improve quality of life in patients with fibromyalgia, and the study was conducted on a sample of 79 patients, and the results showed statistically significant differences in favor of muscle stretching exercises in improving quality of life, and statistically significant differences for resistance training in relieving symptoms. The researchers concluded that stretching exercises are the best at improving bodily function, and resistance training is the best in relieving depression.

Andrade et al., (2018) conducted a study aimed at investigating the effect of strength training analysis on the treatment of fibromyalgia through a review of the experimental research system, where the study included the equivalent of 22 eligible studies, most of which were conducted in the United States by $36 \%$, Finland $23 \%$, Brazil 18\% and Sweden 18\%. The study showed that strength training reduces the number of stress points, fatigue and depression, and improves the quality of life for patients with fibromyalgia, so that the training period ranged from 3-21 weeks, with sessions conducted twice a week, and the main results of these studies included a decrease in pain, fatigue, depression, and anxiety, along with improvements in function and quality of life. Current evidence shows that strength training is beneficial and can be used to treat fibromyalgia.

Sieczkowska et al., (2019) conducted a study aimed at investigating the effect of physical exercise in improving the quality of life of patients with fibromyalgia on a sample of 284 , most of them women with a range of age (30-50). And they were divided into two groups (control and experimental), where they assessed their social, demographic and clinical characteristics, physical exercise, sleep and their quality of life. And sleep was assessed using the Pittsburgh Sleep Quality Index, and quality of life was assessed using the Fibromyalgia 
Impact Questionnaire. The results showed that the control group that did not exercise regularly, its members were using anti-depressants and muscle relaxants, as for those who exercised regularly, they had a better quality of life and had less depression.

Scaturro, et al. (2019) conducted a study aiming to find out the effect of an intensive physical rehabilitation program on the quality of life of patients with fibromyalgia, where the study sample was (60) patients, and the sample was divided into two parts. The first experimental group carried out a physical program consisting of group exercises, laser therapy, tennis (TENS), and a control group, pain and fatigue were measured for the patients of the experimental group using several measures such as a questionnaire on the extent of the effect of myofascial pain, and the program was applied by 40 sessions over a period of 20 weeks. The results showed that there was an improvement in the combined treatment of pain and fatigue and in all areas of quality of life in detail. The experimental group witnessed a significant improvement in part of the pain measures, but there was no improvement in the other measures.

Tomas-Carus et al., (2019) conducted a study aimed at investigating the effect of supervised breathing exercises in women with fibromyalgia, where a quasi-experimental approach was used, the study sample (51) was a sick woman, and they were divided into two groups (control and experimental), and the extent of pain on their pressure points and the extent of the effect of fibromyalgia on daily life were evaluated. After 12 weeks of practicing breathing exercises, the results showed that there were no statistically significant differences between the supervised and non-supervised system. And the researchers concluded that the performance of an unsupervised respiratory program can be as safe and effective as a supervised system. However it has been noted that there may be a tendency for the supervised exercise regimen as it has demonstrated improvement in terms of pain.

Oliver et al., (2019) conducted a study aimed at investigating the effect of a multi-component treatment that improves the health of patients with fibromyalgia within 12 weeks, and the study sample was (64) patients with fibromyalgia, several tests were used to measure the extent of fibromyalgia, the Tampa phobia scale, the (Peek Protocol) index, grip strength, the 6-minute walking test and the grading test. The results showed a significant improvement in depression, pain and walking, and the study recommends that the treatment be applied gradually to patients, excluding patients with moderate to severe depression before starting it.

\section{The Hypothesis of the Study}

1. There are statistically significant differences in the level of pain, muscle strength, mental health, and quality of life between the pre and post measurements and in favor of the post measurements at the significance level $\alpha \geq 0.05$.

\section{The study Determinants}

Spatial determinant: The study program was implemented in two different places, namely the College of Physical Education at the University of Jordan and the Department of Natural Medicine and Rehabilitation at Al-Bashir Hospital of the Jordanian Ministry of Health.

Temporal determinant: The program of this study was implemented in the period from 1-12-2019 to 4 13-2019.

Human determinant: The program was applied to a sample of 9 female patients suffering from chronic muscle pain (fibromyalgia).

\section{Methodology \\ The Study Approach}

The researcher used the experimental method due to its suitability to the nature and circumstances of this study.

\section{The Study Population}

The study population consists of women with chronic muscle pain disease in Jordan.

\section{The Study Sample}

Fourteen women with fibromyalgia were deliberately selected by posting an advertisement on social media and through the Jordanian Association for Chronic Muscle Pain (Fibromyalgia), and after investigating the necessary information and the medical history of all the patients, one patient was excluded because of her anaemia in addition to fibromyalgia, which may affect the results of the study, another patient who had a broken toe was excluded, which led to her being left behind for 3 weeks (12 sessions) in the middle of the treatment period, and 3 patients were excluded for not fully adhering to the treatment sessions, and the final number reached 9 patients. 
Table 1: homogeneity of the study sample in the age variable Arithmetic average Standard deviation Coefficient of variation

$\begin{array}{llll}\text { Age (years) } & 49.25 & 2.43 & 4.93\end{array}$

The table shows the descriptive statistics of the age variable, and the results show that the arithmetic mean value of the age variable has reached (49.25) years. It is noticed that the value of the coefficient of variation indicates the presence of convergence (homogeneity) among the members of the research group, as it reached (4.93\%), and it is a value that falls within the acceptable range of the values of homogeneity, as these values express a normal degree of difference between study participants because they did not exceed $50 \%$ of verification of the homogeneity of individuals of the research sample in the study variables.

First: in pain indicators

Table 2: Description of the pain variable indicators data and the homogeneity of the research sample

\begin{tabular}{|c|c|c|c|c|}
\hline \multicolumn{2}{|c|}{ Pain variable indicators } & \multirow{2}{*}{$\begin{array}{l}\text { Arithmetic } \\
\text { average } \\
1.33\end{array}$} & \multirow{2}{*}{$\begin{array}{l}\text { standard } \\
\text { deviation }\end{array}$} & \multirow{2}{*}{$\begin{array}{l}\text { Coefficient } \\
\text { of variation } \\
75.19\end{array}$} \\
\hline The type of pain & I feel pain like a pulse & & & \\
\hline & I feel striking pain & 1.11 & 1.45 & 130.63 \\
\hline & I feel pain like stabs & 1.78 & 1.20 & 67.42 \\
\hline & I feel sharp pain & 1.78 & 1.09 & 61.24 \\
\hline & I feel pain like cramps & 1.78 & 0.97 & 54.49 \\
\hline & I feel biting pain (gnawing) & 0.89 & 1.05 & 117.98 \\
\hline & I feel a burning pain & 1.67 & 1.12 & 67.07 \\
\hline & I feel constant aching pain & 1.89 & 0.95 & 53.37 \\
\hline & I feel the pain of feeling heaviness & 2.22 & 0.97 & 43.69 \\
\hline & I feel pain when pressing or touching & 2.56 & 0.73 & 28.52 \\
\hline & I feel pain like Rip (chopping) & 1.67 & 1.32 & 79.04 \\
\hline & I feel tired and exhausted pain & 2.33 & 0.87 & 37.34 \\
\hline & I feel the pain of the disease (sickening) & 1.56 & 1.24 & 79.49 \\
\hline & I feel a dreaded pain (scary) & 1.11 & 1.05 & 94.59 \\
\hline & I feel excruciating pain & 1.78 & 1.09 & 61.24 \\
\hline \multicolumn{2}{|c|}{ The severity of the pain } & 7.78 & 2.64 & 33.93 \\
\hline \multicolumn{2}{|c|}{ Best description of pain (overall) } & 3.67 & 1.41 & 38.42 \\
\hline \multicolumn{2}{|c|}{ The period of feeling pain (currently) } & 2.44 & 0.73 & 29.92 \\
\hline
\end{tabular}

The results of Table (2) refer to the values of the arithmetic means and standard deviations, as well as the coefficient of variation in the variables describing pain in the pre-measurement. By reviewing the values of the difference coefficient, it is noticed that most of these values were high as the largest of these values was achieved in the pain type variable (the second question), as this value reached (130.63) and these results express a lack of convergence of pain feeling among the members of the research group. 
Second: Indicators of quality of life

Table 3: Description of the data of the indicators of the variable of quality of life, and the homogeneity of the study sample members

\begin{tabular}{|c|c|c|c|c|}
\hline \multicolumn{2}{|c|}{ Indicators of quality of life } & \multirow{2}{*}{$\begin{array}{l}\text { Arithmetic } \\
\text { average }\end{array}$} & \multirow{2}{*}{$\begin{array}{l}\begin{array}{l}\text { standard } \\
\text { deviation }\end{array} \\
3.91\end{array}$} & \multirow{2}{*}{$\begin{array}{l}\text { Coefficient } \\
\text { of variation } \\
130.33\end{array}$} \\
\hline The amount of & Combing Hair & & & \\
\hline $\begin{array}{l}\text { difficulty caused } \\
\text { by the disease }\end{array}$ & $\begin{array}{l}\text { Walk for } 20 \text { continuous } \\
\text { minutes }\end{array}$ & 4.00 & 4.90 & 122.50 \\
\hline & Preparing a home meal & 3.56 & 2.30 & 64.61 \\
\hline & Sweep, scrub, mop the floors & 5.89 & 3.82 & 64.86 \\
\hline & Lift the grocery bag & 7.11 & 2.67 & 37.55 \\
\hline & Stair climbing (10 steps) & 4.33 & 4.21 & 97.23 \\
\hline & $\begin{array}{l}\text { Sit on the chair for } 45 \text { minutes } \\
\text { straight }\end{array}$ & 7.22 & 3.38 & 46.81 \\
\hline & Bed linen change & 5.33 & 2.87 & 53.85 \\
\hline & Go grocery shopping & 4.67 & 4.09 & 87.58 \\
\hline & Total score & 5.01 & 2.72 & 54.29 \\
\hline \multirow[t]{3}{*}{$\begin{array}{l}\text { The overall effect } \\
\text { of the disease }\end{array}$} & $\begin{array}{l}\text { Chronic muscle pain syndrome } \\
\text { prevented me from achieving } \\
\text { my goals for the week }\end{array}$ & 5.22 & 3.83 & 73.37 \\
\hline & $\begin{array}{l}\text { I was totally bothered by the } \\
\text { symptoms of chronic muscle } \\
\text { pain syndrome }\end{array}$ & 4.56 & 4.36 & 95.61 \\
\hline & Total score & 4.89 & 3.62 & 74.03 \\
\hline \multirow{11}{*}{$\begin{array}{l}\text { The severity of } \\
\text { the disease } \\
\text { symptoms }\end{array}$} & Pain level & 6.89 & 3.41 & 49.49 \\
\hline & Vitality level & 6.33 & 3.39 & 53.55 \\
\hline & The level of stiffness & 6.22 & 4.06 & 65.27 \\
\hline & $\begin{array}{l}\text { How comfortable is it after } \\
\text { sleep }\end{array}$ & 5.89 & 3.52 & 59.76 \\
\hline & Depression level & 4.89 & 3.62 & 74.03 \\
\hline & $\begin{array}{l}\text { The level of problems in } \\
\text { memory }\end{array}$ & 5.78 & 3.80 & 65.74 \\
\hline & Level of anxiety and stress & 5.11 & 4.28 & 83.76 \\
\hline & $\begin{array}{l}\text { Pain level when pressed or } \\
\text { touched }\end{array}$ & 7.44 & 3.00 & 40.32 \\
\hline & $\begin{array}{l}\text { Level of problems in } \\
\text { maintaining balance }\end{array}$ & 3.89 & 3.79 & 97.43 \\
\hline & $\begin{array}{l}\text { Sensitivity level to loud sounds, } \\
\text { bright or fluorescent lights, } \\
\text { smells, and cold }\end{array}$ & 8.11 & 2.80 & 34.53 \\
\hline & Total score & 6.06 & 2.65 & 43.73 \\
\hline \multicolumn{2}{|c|}{ Total score for quality of life } & 5.32 & 2.81 & 52.82 \\
\hline
\end{tabular}

The results of Table (3) refer to the values of the arithmetic means and the standard deviations, as well as the coefficient of variation in the indicators of quality of life in the pre-measurement, by reviewing the values of the coefficient of variation, it is noted that most of these values were high, as the largest of these values was achieved in the variable of the first question from the questions of quantitative indicators of difficulty resulting from pain as it reached (130.33) these results express a lack of convergence in the expression of the members of the research group about their satisfaction or their sense of the indicators of quality of life represented in this research by the difficulty resulting from the disease and the overall effect of the disease and the severity of disease symptoms. 
Third: mental health indicators

Table 4: Description of the data of the indicators of the mental health variable and the homogeneity of the individuals of the research sample

\begin{tabular}{|c|c|c|c|c|}
\hline \multicolumn{2}{|c|}{ Mental health indicators } & $\begin{array}{l}\text { Arithmetic } \\
\text { average }\end{array}$ & $\begin{array}{l}\text { standard } \\
\text { deviation }\end{array}$ & $\begin{array}{l}\text { Coefficient } \\
\text { of variation }\end{array}$ \\
\hline \multirow{15}{*}{$\begin{array}{l}\text { Psychological } \\
\text { health }\end{array}$} & I feel nervous & 1.67 & 1.00 & 59.88 \\
\hline & $\begin{array}{l}\text { I still enjoy the things that I used to } \\
\text { enjoy in the past }\end{array}$ & 2.00 & 0.71 & 35.50 \\
\hline & $\begin{array}{l}\text { I feel afraid, as if something bad or } \\
\text { terrible is going to happen }\end{array}$ & 1.22 & 1.20 & 98.36 \\
\hline & $\begin{array}{l}\text { I have fun, laugh and see the happy } \\
\text { side of everything }\end{array}$ & 1.11 & 0.78 & 70.27 \\
\hline & $\begin{array}{l}\text { There are suspicious and worrisome } \\
\text { thoughts running through my mind }\end{array}$ & 0.89 & 1.05 & 117.98 \\
\hline & I feel happy or elated & 1.22 & 0.67 & 54.92 \\
\hline & I can sit in peace and relaxation & 1.78 & 0.67 & 37.64 \\
\hline & I feel lazy or slowed down & 2.11 & 0.93 & 44.08 \\
\hline & $\begin{array}{l}\text { I feel fear, as if something is in my } \\
\text { stomach }\end{array}$ & 0.67 & 0.71 & 105.97 \\
\hline & I lost interest in my appearance & 1.22 & 0.97 & 79.51 \\
\hline & $\begin{array}{l}\text { I feel anxious and uncomfortable } \\
\text { and there was something to do }\end{array}$ & 1.67 & 0.87 & 52.10 \\
\hline & I am looking to enjoy the things & 1.67 & 0.87 & 52.10 \\
\hline & I suddenly feel anxious & 1.56 & 1.01 & 64.74 \\
\hline & $\begin{array}{l}\text { I can enjoy a program or topic on } \\
\text { the radio or television or in a book }\end{array}$ & 1.67 & 1.12 & 67.07 \\
\hline & Total score & 1.46 & 0.53 & 36.30 \\
\hline
\end{tabular}

The results of Table (4) refer to the values of the arithmetic averages and standard deviations, as well as the coefficient of difference in mental health in the pre-measurement. By reviewing the values of the difference coefficient, it is noted that most of these values were high, as the largest of these values was achieved in the fifth question of the mental health questions, as this value reached (117.98) and these results express a lack of convergence in the expression of mental health among the members of the research group.

\section{Fourth: muscle strength tests}

Table 5: Description of the muscle strength indicators data and the homogeneity of the research sample

\begin{tabular}{llll} 
Muscle strength tests & Arithmetic average & standard deviation & $\begin{array}{c}\text { Coefficient } \\
\text { of variation }\end{array}$ \\
\hline Right grip force. Kg & & & 39.76 \\
Left grip strength. Kg & 21.10 & 8.39 & 34.00 \\
Bottom strength (repeat) & 19.06 & 6.48 & 120.68 \\
Abdominal muscle strength (repeat) & 7.00 & 22.12 & 83.57
\end{tabular}

The results of Table (5) refer to the values of the arithmetic means and the standard deviations, as well as the coefficient of variation in the variables of muscle strength in the pre-measurement. By reviewing the 
values of the coefficient of variation, it is noted that most of these values were high, as the largest of these values had been achieved in the variable strength of the lower part, as this value reached (120.68). These results express the divergence of muscle strength values through the four tests shown among the members of the research group.

\title{
Data collection tools
}

The researcher applied a proposed qualification program where the necessary scientific transactions were carried out, and the researcher used specific tests to measure each of the variables, so that the following measures were used:

First: The short-form McGill Pain Questionnaire, translated into Arabic, Terkawi et al., 2017).

Second: Muscle strength tests for: (Mathiowetz et al., 1984).

Muscles of the upper limbs: Power grip device from Jamar Espana-Romero company and

- $\quad$ Abdominal muscles: The Curl-up Test, Knudson and Johnston, 1995.

- $\quad$ Lower extremity muscles: the squat test.

Third: the scale of anxiety and depression (HADS), the hospital anxiety and depression scale, translated into Arabic (Malasi et al., 1991).

Fourth: Fibromyalgia impact scale, translated into Arabic (Abu-Dahab et al, 2014).

\author{
The Study Variables \\ 1. Independent variable: \\ - The proposed pilot program. \\ 2. Dependent variables \\ - Pain \\ - $\quad$ Muscle strength \\ - $\quad$ Psychological health \\ - Quality of life
}

\section{Validity of the study tool}

The program was presented to a jury consisting of 4 professors in the field of sports and health sciences, 3 associate professors in the field of physical therapy, and 3 physicians from physical medicine and rehabilitation specialists.

\section{The Study Procedures}

The researcher designed a comprehensive and diversified rehabilitation treatment program that combines therapeutic sports and psychological rehabilitation by referring to modern scientific and medical references specialized in the field, and she examined its validity by presenting it to arbitrators with expertise in the field. Then the researcher applied this program to the study sample consisting of 14 women before excluding a number of them for not meeting the conditions of scientific research from the obligation to attend the sessions, bringing the number to 9 women, then she applied a set of fixed tests and pre-measurements on the study variables before applying the proposed program for a period of 12 weeks for both groups by 3 weekly sessions, the duration of the session in the first 6 weeks was one hour that contained breathing exercises, stretching and muscle strength using weights tied on the wrists of half a kilogram and others on feet of one kilogram and by 10 repetitions of each exercise for each group as the number of groups was 2, then the duration of the session in the following six weeks was increased to an hour and a half, so that the weights attached to the wrists were raised to one kilogram and the weights of the feet to one and a half kilograms per foot, and the number of groups for strength training was increased to 3 groups, in addition, a cognitive behavioral therapy session was conducted in a group, which included awareness and education regarding the etiology of the disease for a period of two hours and by 6 sessions during the 12 weeks, with one session every two weeks.

\section{The Data Analysis}

The researcher analyzed the test results statistically in order to achieve the study's objectives and questions, as the non-parametric Wilcoxon test was used, which does not depend on the values of arithmetic averages and standard deviations of the research variables, rather, it depends on the order of these values, because the research sample is relatively small (less than 30) and because the dispersion and difference between the members of the research sample is somewhat high. It should be noted that this type of statistical test does not require a requirement to disclose the approach of distributing data from a normal distribution, thus, there was no need to use it in the hypotheses of the study, and below is a presentation of the results of hypothesis testing related to the effect of the program used. 
View results

First: displaying the results of the first variable (pain)

There are statistically significant differences at $\alpha=0.05$ between the average of the pre and post measurements in favor of the post measures over the pain variable. And to verify this hypothesis, it was tested by Wilcoxon's nonparametric test, and the following tables show the results of this hypothesis:

Table 6: averages of types of pain that the research sample subjected to in the pre and post measurements

\begin{tabular}{|c|c|c|c|c|c|}
\hline \multirow[t]{2}{*}{ Kinds of pain } & \multirow[t]{2}{*}{$\mathbf{N}$} & \multicolumn{2}{|c|}{ Pre- measurements } & \multicolumn{2}{|c|}{ post measurements } \\
\hline & & $\begin{array}{l}\text { Arithmetic } \\
\text { average }\end{array}$ & $\begin{array}{l}\text { Standard } \\
\text { deviation }\end{array}$ & $\begin{array}{l}\text { Arithmetic } \\
\text { average }\end{array}$ & $\begin{array}{l}\text { Standard } \\
\text { deviation }\end{array}$ \\
\hline I feel pain like a pulse & 9 & 1.33 & 1.00 & 1.33 & 1.12 \\
\hline I feel thumping pain & 9 & 1.11 & 1.45 & 0.67 & 0.71 \\
\hline I feel pain like stabs & 9 & 1.78 & 1.20 & 0.67 & 0.71 \\
\hline I feel sharp pain & 9 & 1.78 & 1.09 & 1.00 & 1.12 \\
\hline I feel pain like cramps & 9 & 1.78 & 0.97 & 1.22 & 0.83 \\
\hline $\begin{array}{l}\text { I feel biting pain } \\
\text { (gnawing) }\end{array}$ & 9 & 0.89 & 1.05 & 0.56 & 0.53 \\
\hline I feel a burning pain & 9 & 1.67 & 1.12 & 1.11 & 0.78 \\
\hline $\begin{array}{l}\text { I feel constant aching } \\
\text { pain }\end{array}$ & 9 & 1.89 & 0.93 & 1.44 & 1.13 \\
\hline $\begin{array}{l}\text { I feel the pain of } \\
\text { feeling heaviness }\end{array}$ & 9 & 2.22 & 0.97 & 1.22 & 0.67 \\
\hline $\begin{array}{l}\text { I feel pain when } \\
\text { pressing or touching }\end{array}$ & 9 & 2.56 & 0.73 & 1.67 & 1.22 \\
\hline $\begin{array}{l}\text { I feel pain like tearing } \\
\text { (chopping) }\end{array}$ & 9 & 1.67 & 1.32 & 0.56 & 0.73 \\
\hline $\begin{array}{l}\text { I feel tired and } \\
\text { exhausting pain }\end{array}$ & 9 & 2.33 & 0.87 & 1.56 & 1.01 \\
\hline $\begin{array}{l}\text { I feel the pain of the } \\
\text { disease (sickening) }\end{array}$ & 9 & 1.56 & 1.24 & 0.44 & 1.01 \\
\hline $\begin{array}{l}\text { I feel dreaded pain } \\
\text { (scary) }\end{array}$ & 9 & 1.11 & 1.05 & 0.67 & 0.87 \\
\hline $\begin{array}{l}\text { I feel excruciating } \\
\text { pain }\end{array}$ & 9 & 1.78 & 1.09 & 0.89 & 0.78 \\
\hline $\begin{array}{l}\text { The severity of the } \\
\text { pain }\end{array}$ & 9 & 7.78 & 2.64 & 4.67 & 2.29 \\
\hline $\begin{array}{l}\text { Best description of } \\
\text { pain (overall) }\end{array}$ & 9 & 3.67 & 1.41 & 2.78 & 0.97 \\
\hline The period of feeling & 9 & 2.44 & 0.73 & 1.89 & 0.60 \\
\hline
\end{tabular}




\begin{tabular}{|c|c|c|c|c|c|c|}
\hline The type of pain & $\begin{array}{l}\text { Rank } \\
\text { indication }\end{array}$ & $\begin{array}{l}\text { Total } \\
\text { ranks }\end{array}$ & $\begin{array}{l}\text { The } \\
\text { number } \\
\text { of ranks }\end{array}$ & $\begin{array}{l}\text { Average } \\
\text { ranks }\end{array}$ & $\begin{array}{l}\mathrm{Z} \\
\text { value }\end{array}$ & $\begin{array}{l}\text { Indication } \\
\text { level }\end{array}$ \\
\hline \multirow[t]{2}{*}{ I feel pain like a pulse } & Negative & 14.50 & 3 & 4.83 & 0.087 & 0.931 \\
\hline & Positive & 13.50 & 4 & 3.38 & & \\
\hline \multirow[t]{2}{*}{ I feel thumping pain } & Negative & 11.00 & 3 & 3.67 & 0.962 & 0.336 \\
\hline & Positive & 4.00 & 2 & 2.00 & & \\
\hline \multirow[t]{2}{*}{ I feel pain like stabs } & Negative & 26.00 & 6 & 4.33 & 2.058 & $* 0.040$ \\
\hline & Positive & 2.00 & 1 & 2.00 & & \\
\hline \multirow[t]{2}{*}{ I feel sharp pain } & Negative & 33.50 & 7 & 4.79 & 1.329 & 0.184 \\
\hline & Positive & 11.50 & 2 & 5.75 & & \\
\hline \multirow[t]{2}{*}{ I feel pain like cramps } & Negative & 22.00 & 5 & 4.40 & 1.406 & 0.160 \\
\hline & Positive & 6.00 & 2 & 3.00 & & \\
\hline \multirow{2}{*}{$\begin{array}{l}\text { I feel biting pain } \\
\text { (gnawing) }\end{array}$} & Negative & 11.00 & 3 & 3.67 & 0.966 & 0.334 \\
\hline & Positive & 4.00 & 2 & 2.00 & & \\
\hline \multirow[t]{2}{*}{ I feel a burning pain } & Negative & 26.00 & 6 & 4.33 & 1.155 & 0.248 \\
\hline & Positive & 10.00 & 2 & 5.00 & & \\
\hline \multirow{2}{*}{$\begin{array}{l}\text { I feel constant aching } \\
\text { pain }\end{array}$} & Negative & 23.50 & 5 & 4.70 & 0.791 & 0.429 \\
\hline & Positive & 12.50 & 3 & 4.17 & & \\
\hline \multirow{2}{*}{$\begin{array}{l}\text { I feel the pain of } \\
\text { feeling heaviness }\end{array}$} & Negative & 25.50 & 6 & 4.25 & 1.983 & $* 0.047$ \\
\hline & Positive & 2.50 & 1 & 2.5 & & \\
\hline \multirow{2}{*}{$\begin{array}{l}\text { I feel pain when } \\
\text { pressing or touching }\end{array}$} & Negative & 23.00 & 6 & 3.83 & 1.582 & 0.114 \\
\hline & Positive & 5.00 & 1 & 5.00 & & \\
\hline \multirow{2}{*}{$\begin{array}{l}\text { I feel pain like tearing } \\
\text { (chopping) }\end{array}$} & Negative & 26.00 & 6 & 4.33 & 2.058 & $* 0.040$ \\
\hline & Positive & 2.00 & 1 & 2.00 & & \\
\hline \multirow{2}{*}{$\begin{array}{l}\text { I feel tired and } \\
\text { exhausting pain }\end{array}$} & Negative & 28.00 & 6 & 4.67 & 1.443 & 0.149 \\
\hline & Positive & 8.00 & 2 & 4.00 & & \\
\hline \multirow{2}{*}{$\begin{array}{l}\text { I feel the pain of the } \\
\text { disease (sickening) }\end{array}$} & Negative & 15.00 & 5 & 3.00 & 2.060 & $* 0.039$ \\
\hline & Positive & 0.00 & 0 & 0.00 & & \\
\hline \multirow{2}{*}{$\begin{array}{l}\text { I feel a dreaded pain } \\
\text { (scary) }\end{array}$} & Negative & 15.50 & 5 & 3.10 & 1.081 & 0.279 \\
\hline & Positive & 5.50 & 1 & 5.50 & & \\
\hline \multirow[t]{2}{*}{ I feel excruciating pain } & Negative & 25.00 & 6 & 4.17 & 1.930 & 0.054 \\
\hline & Positive & 3.00 & 1 & 3.00 & & \\
\hline \multirow{2}{*}{$\begin{array}{l}\text { The severity of the } \\
\text { pain }\end{array}$} & Negative & 32.50 & 7 & 4.64 & 2.038 & $* 0.042$ \\
\hline & Positive & 3.50 & 1 & 3.50 & & \\
\hline \multirow{2}{*}{$\begin{array}{l}\text { Best description of } \\
\text { pain (overall) }\end{array}$} & Negative & 27.00 & 5 & 5.40 & 1.292 & 0.196 \\
\hline & Positive & 9.00 & 3 & 3.00 & & \\
\hline \multirow{2}{*}{$\begin{array}{l}\text { The period of feeling } \\
\text { pain (currently) }\end{array}$} & Negative & 16 & 5 & 3.20 & 1.179 & 0.238 \\
\hline & Positive & 5.00 & 1 & 5.00 & & \\
\hline
\end{tabular}

Table (7) indicates the results of the Wilcoxon test between the pre and post measurements of the pain type indicators. By reviewing the values of the test significance levels and comparing them with the value 0.05 , it becomes evident that the value of the significance level calculated for the types of pain (stabs), (painful constant), (pressure or touch) and (tired or exhausted) and calculated for the pain intensity variable was less than 0.05 , where these values reached $(0.040),(0.047),(0.040),(0.039)$ and $(0.042)$ respectively. And this means that there are statistically significant differences between the pre and post measurements of the four types of pain referred to, as well as the pain intensity variable, whereas, the significance of the difference was in favor of the post measurement with the better arithmetic mean, which expressed the lower values of the degree of pain in the four types referred to, in addition to the variable of pain intensity (you can use Table No. 6, which shows the 
arithmetic averages) while the values of the significance level for the rest of the indices of types of pain, and for the variable best description of pain and the variable for the period of perception of pain were greater than 0.05 , indicating that they were not statistically significant for the differences between the pre and post measurements.

Secondly, presenting the results of the second variable (quality of life)

There are statistically significant differences at the level of $\alpha=0.05$ between the averages of the dimensional and the pre-measurements in favor of the dimensional measurements on the indicators of the quality-of-life scale. To verify this hypothesis, it was tested through Wilcoxon's nonparametric test, and the following tables show the results of this hypothesis:

\section{Indicators of quality of life in terms of the severity of the disease}

Table 8: averages of difficulty resulting from the disease among the research sample in the pre and post measures

\begin{tabular}{|c|c|c|c|c|c|}
\hline \multirow{2}{*}{\multicolumn{2}{|c|}{$\begin{array}{l}\text { Quality of life - the amount } \\
\text { of difficulty caused by the } \\
\text { disease }\end{array}$}} & \multicolumn{2}{|c|}{ Pre- Measurement } & \multicolumn{2}{|c|}{ Post - Measurement } \\
\hline & & $\begin{array}{l}\text { Arithmetic } \\
\text { average }\end{array}$ & $\begin{array}{l}\text { Standard } \\
\text { deviation }\end{array}$ & $\begin{array}{l}\text { Arithmetic } \\
\text { average }\end{array}$ & $\begin{array}{l}\text { Standard } \\
\text { deviation }\end{array}$ \\
\hline Combing Hair & 9 & 3.00 & 3.91 & 0.67 & 0.71 \\
\hline $\begin{array}{l}\text { Walk for } 20 \text { continuous } \\
\text { minutes }\end{array}$ & 9 & 4.00 & 4.90 & 2.44 & 2.65 \\
\hline Preparing a home meal & 9 & 3.56 & 2.30 & 2.89 & 2.76 \\
\hline Sweep, scrub, mop the floors & 9 & 5.89 & 3.82 & 3.33 & 3.04 \\
\hline Lift the grocery bag & 9 & 7.11 & 2.67 & 3.56 & 2.74 \\
\hline Stair climbing (10 steps) & 9 & 4.33 & 4.21 & 3.22 & 3.49 \\
\hline $\begin{array}{l}\text { Sit on the chair for } 45 \\
\text { minutes straight }\end{array}$ & 9 & 7.22 & 3.38 & 4.44 & 3.57 \\
\hline Bed linen change & 9 & 5.33 & 2.87 & 2.67 & 2.69 \\
\hline $\begin{array}{l}\text { Going to the grocery } \\
\text { shopping }\end{array}$ & 9 & 4.67 & 4.09 & 2.78 & 2.86 \\
\hline Total marks & 9 & 5.01 & 2.72 & 2.89 & 2.13 \\
\hline
\end{tabular}


Table 9: Wilcoxon test results between pre and post measures of indicators of quality of life - the amount of difficulty resulting from the disease

\begin{tabular}{|c|c|c|c|c|c|c|}
\hline $\begin{array}{l}\text { Quality of life - the amount } \\
\text { of difficulty caused by the } \\
\text { disease }\end{array}$ & $\begin{array}{l}\text { Rank } \\
\text { indication }\end{array}$ & $\begin{array}{l}\text { Total } \\
\text { ranks }\end{array}$ & $\begin{array}{l}\text { The number } \\
\text { of ranks }\end{array}$ & $\begin{array}{l}\text { Average } \\
\text { ranks }\end{array}$ & $\begin{array}{l}\mathrm{Z} \\
\text { value }\end{array}$ & $\begin{array}{l}\text { Indication } \\
\text { level }\end{array}$ \\
\hline \multirow[t]{2}{*}{ Combing Hair } & Negative & 16.50 & 4 & 4.13 & 1.265 & 0.206 \\
\hline & Positive & 4.50 & 2 & 2.25 & & \\
\hline \multirow{2}{*}{$\begin{array}{l}\text { Walk for } 20 \text { continuous } \\
\text { minutes }\end{array}$} & Negative & 15.50 & 4 & 3.88 & 1.051 & 0.293 \\
\hline & Positive & 5.50 & 2 & 2.75 & & \\
\hline \multirow[t]{2}{*}{ Preparing a home meal } & Negative & 28.00 & 6 & 4.67 & 0.654 & 0.513 \\
\hline & Positive & 17.00 & 3 & 5.67 & & \\
\hline \multirow[t]{2}{*}{ Sweep, scrub, mop the floors } & Negative & 28.00 & 6 & 4.67 & 1.400 & 0161 \\
\hline & Positive & 8.00 & 2 & 4.00 & & \\
\hline \multirow[t]{2}{*}{ Lift the grocery bag } & Negative & 41.00 & 7 & 5.86 & 2.23 & $* 0.028$ \\
\hline & Positive & 4.00 & 2 & 2.00 & & \\
\hline \multirow[t]{2}{*}{ Stair climbing (10 steps) } & Negative & 14.00 & 4 & 3.50 & 0.734 & 0.463 \\
\hline & Positive & 7.00 & 2 & 3.50 & & \\
\hline \multirow{2}{*}{$\begin{array}{l}\text { Sit on the chair for } 45 \\
\text { minutes straight }\end{array}$} & Negative & 31.00 & 7 & 4.43 & 1.825 & 0.068 \\
\hline & Positive & 5.00 & 1 & 5.00 & & \\
\hline \multirow[t]{2}{*}{ Bed linen change } & Negative & 38.00 & 7 & 5.43 & 1.843 & 0.065 \\
\hline & Positive & 7.00 & 2 & 3.50 & & \\
\hline \multirow{2}{*}{$\begin{array}{l}\text { Going to the grocery } \\
\text { shopping }\end{array}$} & Negative & 26.00 & 5 & 5.20 & 1.124 & 0.261 \\
\hline & Positive & 10.00 & 3 & 3.33 & & \\
\hline \multirow[t]{2}{*}{ Total marks } & Negative & 35.50 & 7 & 5.07 & 1.541 & 0.123 \\
\hline & Positive & 9.50 & 2 & 4.75 & & \\
\hline
\end{tabular}

Table No. (9) indicates the results of the Wilcoxon test between the pre and post measurements of quality-of-life indicators, expressed by the degree of difficulty resulting from the disease. And by reviewing the values of the test significance levels and comparing them with the value 0.05 , it is evident that the value of the significance level calculated for pain difficulty resulting from the disease (raising the grocery bag) was less than 0.05 , where this value reached (0.028), which means that there are statistically significant differences between the pre and post measurements in this variable, so that the significance of the difference was in favor of the post measurement, which has the better arithmetic mean, which expresses the low values of the degree of difficulty referred to in addition to that (you can use the arithmetic averages table No. 8) While the significance level values for the rest of the indicators of degree of difficulty resulting from the disease were greater than 0.05 , indicating their lack of statistical significance for the differences between the pre and post measures.

2. Indicators of the quality of life in terms of the overall impact of the disease 
Table 10: averages of indicators of quality of life in terms of the overall effect of the disease in the pre and post measures

\begin{tabular}{|c|c|c|c|c|c|}
\hline \multirow{2}{*}{$\begin{array}{l}\text { Quality } \\
\text { overall } \\
\text { disease }\end{array}$} & \multirow[t]{2}{*}{ number } & \multicolumn{2}{|c|}{ Pre- measurement } & \multicolumn{2}{|c|}{ Post- measurement } \\
\hline & & $\begin{array}{l}\text { Arithmetic } \\
\text { average }\end{array}$ & $\begin{array}{l}\text { Standard } \\
\text { deviation }\end{array}$ & $\begin{array}{l}\text { Arithmetic } \\
\text { average }\end{array}$ & $\begin{array}{l}\text { Standard } \\
\text { deviation }\end{array}$ \\
\hline $\begin{array}{l}\text { Chronic muscle pain } \\
\text { syndrome prevented me } \\
\text { from achieving my goals } \\
\text { for the week }\end{array}$ & 9 & 5.22 & 3.83 & 2.78 & 2.64 \\
\hline $\begin{array}{l}\text { I was totally bothered by } \\
\text { the symptoms of chronic } \\
\text { muscle pain syndrome }\end{array}$ & 9 & 4.56 & 4.36 & 3.00 & 2.87 \\
\hline Total degree & 9 & 4.89 & 3.62 & 2.89 & 2.65 \\
\hline
\end{tabular}

Table 11: Wilcoxon test results between pre and post measures of indicators of quality of life - the overall effect of the disease Quality of life - the overall effect of the disease

muscle

Rank Total

indication ranks

$$
\text { The number of }
$$
ranks

Average ranks

$\mathbf{Z}$ value

Indication

Chronic

pain syndrome

prevented me from achieving my goals for the week

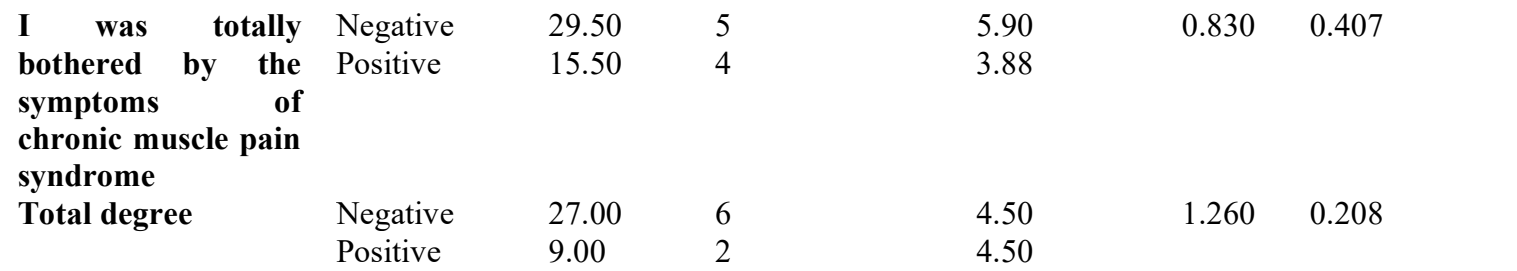

Table No. (11) indicates the results of the Wilcoxon test between the pre- and post-measurements and the quality of life indicators expressed by the overall effect of the disease. By reviewing the test significance levels values and comparing them with the value 0.05 , it was found that the significance level values for the overall effect caused by the disease were greater than 0.05 , which indicates its lack of statistical significance for the differences between the pre and post measurements. 
Indicators of quality of life in terms of severity of disease symptoms

Table 12: averages of indicators of quality of life in terms of severity of disease symptoms in the pre and post measures

Quality of life - the severity of disease symptoms

Pain level

Vitality level

The level of stiffness

Comfort level after sleep

Depression level

The level of problems in memory

Level of anxiety and stress

The level of pain when pressed

or touched

Level of problems in maintaining balance

Sensitivity level to loud sounds, bright or fluorescent lights, smells, and cold

The total degree of severity of disease symptoms

Total score for quality of life

\section{N}

Pre- measurement

Arithmetic
average

$9 \quad 6.89$

$9 \quad 4.22$

$9 \quad 6.22$

$9 \quad 5.89$

$9 \quad 4.89$

$9 \quad 5.78$

$9 \quad 5.11$

7.44

3.89

8.11

$9 \quad 5.84$

$9 \quad 4.56$

3.41

3.39

3.52

3.62

3.80

3.79

2.80

2.65

2.81
Post - measurement

$\begin{array}{lll}\begin{array}{l}\text { Standard } \\ \text { deviation }\end{array} & \begin{array}{l}\text { Arithmetic } \\ \text { average }\end{array} & \begin{array}{l}\text { Standard } \\ \text { deviation }\end{array} \\ 3.41 & 4.78 & 3.63\end{array}$

6.33

3.46

4.06

4.78

2.54

4.44

2.89

2.93

5.00

3.50

4.28

4.11

3.10

3.00

4.11

2.85

2.78

5.22

2.39

4.44

2.38

4.18

2.09 
Table 13: Wilcoxon test results between pre- and post-measures of indicators of quality of life - severity of disease symptoms

\begin{tabular}{|c|c|c|c|c|c|c|}
\hline $\begin{array}{l}\text { The severity of } \\
\text { the symptoms of } \\
\text { the disease }\end{array}$ & $\begin{array}{l}\text { Rank } \\
\text { indication }\end{array}$ & $\begin{array}{l}\text { Total } \\
\text { ranks }\end{array}$ & $\begin{array}{l}\text { The number of } \\
\text { ranks }\end{array}$ & $\begin{array}{l}\text { Average } \\
\text { ranks }\end{array}$ & $Z$ value & $\begin{array}{l}\text { Indication } \\
\text { level }\end{array}$ \\
\hline \multirow[t]{2}{*}{ Pain level } & Negative & 27.50 & 6 & 4.58 & 1.334 & 0.182 \\
\hline & Positive & 8.50 & 2 & 4.25 & & \\
\hline \multirow[t]{2}{*}{ Vitality level } & Negative & 32.00 & 6 & 5.33 & 1.129 & 0.259 \\
\hline & Positive & 13.00 & 3 & 4.33 & & \\
\hline \multirow{2}{*}{$\begin{array}{l}\text { The level of } \\
\text { stiffness }\end{array}$} & Negative & 29.00 & 6 & 4.83 & 0.778 & 0.437 \\
\hline & Positive & 16.00 & 3 & 5.33 & & \\
\hline \multirow{4}{*}{$\begin{array}{l}\text { Comfort level } \\
\text { after sleep } \\
\text { Depression level }\end{array}$} & Negative & 23.50 & 5 & 4.70 & 0.775 & 0.438 \\
\hline & Positive & 12.50 & 3 & 4.17 & & \\
\hline & Negative & 21.00 & 5 & 4.20 & 0.1 .187 & 0.235 \\
\hline & Positive & 7.00 & 2 & 3.50 & & \\
\hline \multirow{2}{*}{$\begin{array}{ll}\text { The level of } \\
\text { problems } & \text { in } \\
\text { memory } & \end{array}$} & Negative & 23.50 & 4 & 5.88 & 0.776 & 0.438 \\
\hline & Positive & 12.50 & 4 & 3.13 & & \\
\hline \multirow{4}{*}{$\begin{array}{l}\text { Level of anxiety } \\
\text { and stress } \\
\text { The level of pain } \\
\text { when pressed or } \\
\text { touched }\end{array}$} & Negative & 16.50 & 3 & 5.50 & 0.424 & 0.671 \\
\hline & Positive & 11.50 & 4 & 2.88 & & \\
\hline & Negative & 40.50 & 8 & 5.06 & 2.138 & $* 0.033$ \\
\hline & Positive & 4.50 & 1 & 4.50 & & \\
\hline \multirow{2}{*}{$\begin{array}{ll}\text { Level } & \text { of } \\
\text { problems } & \text { in } \\
\text { maintaining } & \\
\text { balance } & \end{array}$} & Negative & 21.00 & 5 & 4.20 & 1.190 & 0.234 \\
\hline & Positive & 7.00 & 2 & 3.50 & & \\
\hline $\begin{array}{l}\text { Sensitivity level } \\
\text { to loud sounds, }\end{array}$ & Negative & 37.50 & 8 & 4.69 & 1.782 & 0.075 \\
\hline $\begin{array}{l}\text { to loud sounds, } \\
\text { bright } \\
\text { fluorescent lights, } \\
\text { smells, and cold }\end{array}$ & Positive & 7.50 & 1 & 7.50 & & \\
\hline The total degree & Negative & 35.00 & 6 & 5.83 & 1.481 & 0.139 \\
\hline $\begin{array}{l}\text { of severity of } \\
\text { disease symptoms }\end{array}$ & Positive & 10.00 & 3 & 3.33 & & \\
\hline Total score for & Negative & 34.00 & 7 & 4.86 & 1.362 & 0.173 \\
\hline quality of life & Positive & 11.00 & 2 & 5.50 & & \\
\hline
\end{tabular}

Table No. (13) indicates the results of the Wilcoxon test between the pre and post measurements of quality-of-life indicators, expressed by the severity of the disease symptoms. By reviewing the test significance levels values and comparing them with the value 0.05 , it turns out that the calculated significance level value for the severity of the disease symptoms for (the level of pain when pressing or touching) was less than 0.05 , where this value reached (0.033), which means that there are statistically significant differences between the pre and post measurements in this variable, so that the significance of the difference was in favor of the post measurement, which has the better arithmetic mean, which explained the decrease in the severity of disease symptoms in the aforementioned point (you can use the previous arithmetic averages table No. 12), while the significance level values for the rest of the disease symptom severity points were greater than 0.05 , indicating that they are statistically insignificant for the differences between the pre and post measures.

\section{Presentation of the results of the third variable (mental health)}

There are statistically significant differences at the level of $\alpha=0.05$ between the means of the pre and post measures in favor of the post measures on the indicators of the mental health scale. 
Table 14: averages of mental health indicators in the pre and post measures

Mental health indicators

I feel nervous

I still enjoy the things that I used to enjoy in the past

I feel afraid, as if something bad or $9 \quad 1.22$ terrible is going to happen

I have fun, laugh and see the happy $\quad 9 \quad 0.89$ side of everything

There are suspicious and worrisome thoughts running through my mind

I feel happy and cheerful

I can sit in peace and relaxation

$9 \quad 2.11$

I feel lazy or slowed down

I feel fear, as if something is in my $\quad 9 \quad 0.67$ stomach

I lost interest in my appearance $\quad 9-1.22$

I feel anxious and uncomfortable as 9

if there is something $I$ have to do

I am looking to enjoy the things

$9 \quad 0.78$

I suddenly feel anxious

$9 \quad 1.56$

I can enjoy a program or topic on $9 \quad 1.22$ the radio or television or in a book

Total of mental health
Post - measurement

$\begin{array}{lll}\begin{array}{l}\text { Standard } \\ \text { deviation }\end{array} & \begin{array}{l}\text { Arithmetic } \\ \text { average }\end{array} & \begin{array}{l}\text { Standard } \\ \text { deviation }\end{array} \\ 1.00 & 1.33 & 1.00\end{array}$

$\begin{array}{lll}0.71 & 2.00 & 0.73\end{array}$

$\begin{array}{lll}1.20 & 0.89 & 0.93\end{array}$

$\begin{array}{lll}0.78 & 1.11 & 0.78\end{array}$

$\begin{array}{lll}1.05 & 0.78 & 0.83\end{array}$

$\begin{array}{lll}0.67 & 1.22 & 0.50\end{array}$

$\begin{array}{lll}0.67 & 1.78 & 0.71\end{array}$

$\begin{array}{lll}0.93 & 1.89 & 0.78\end{array}$

$\begin{array}{lll}0.71 & 0.67 & 0.71\end{array}$

$\begin{array}{lll}0.97 & 1.00 & 0.71\end{array}$

$\begin{array}{lll}0.87 & 1.56 & 0.88\end{array}$

$\begin{array}{lll}0.87 & 1.67 & 0.67\end{array}$

$\begin{array}{lll}1.01 & 0.78 & 0.67\end{array}$

$\begin{array}{lll}1.12 & 1.67 & 1.20\end{array}$

$\begin{array}{lll}0.53 & 1.31 & 0.42\end{array}$


Table 15: Wilcoxon test results between pre and post measures of mental health indicators

\begin{tabular}{|c|c|c|c|c|c|c|}
\hline Mental health indicators & $\begin{array}{l}\text { Rank } \\
\text { indication }\end{array}$ & $\begin{array}{l}\text { Total } \\
\text { ranks }\end{array}$ & $\begin{array}{l}\text { The } \\
\text { number } \\
\text { of ranks }\end{array}$ & $\begin{array}{l}\text { Average } \\
\text { ranks }\end{array}$ & $\begin{array}{l}\mathrm{Z} \\
\text { value }\end{array}$ & $\begin{array}{l}\text { Indication } \\
\text { level }\end{array}$ \\
\hline \multirow[t]{2}{*}{ I feel nervous } & Negative & 8.00 & 3 & 2.67 & \multirow[t]{2}{*}{1.134} & \multirow[t]{2}{*}{0.257} \\
\hline & Positive & 2.00 & 1 & 2.00 & & \\
\hline I still enjoy the things that & Negative & 21.00 & 5 & 4.20 & \multirow[t]{2}{*}{1.265} & \multirow[t]{2}{*}{0.206} \\
\hline I used to enjoy in the past & Positive & 7.00 & 2 & 3.50 & & \\
\hline I feel afraid, as if & Negative & 6.00 & 3 & 2.00 & \multirow[t]{2}{*}{1.732} & \multirow[t]{2}{*}{0.083} \\
\hline $\begin{array}{l}\text { something bad or terrible } \\
\text { is going to happen }\end{array}$ & Positive & 0.00 & 0 & 0.00 & & \\
\hline I have fun, laugh and see & Negative & 14.00 & 4 & 3.50 & \multirow[t]{2}{*}{0.816} & \multirow[t]{2}{*}{0.414} \\
\hline $\begin{array}{l}\text { the happy side of } \\
\text { everything }\end{array}$ & Positive & 7.00 & 2 & 3.50 & & \\
\hline \multirow{2}{*}{$\begin{array}{l}\text { There are suspicious and } \\
\text { worrisome thoughts } \\
\text { running through my mind }\end{array}$} & Negative & 9.00 & 3 & 3.00 & \multirow[t]{2}{*}{0.447} & \multirow[t]{2}{*}{0.655} \\
\hline & Positive & 6.00 & 2 & 3.00 & & \\
\hline \multirow{2}{*}{ I feel happy and cheerful } & Negative & 7.50 & 3 & 2.50 & \multirow[t]{2}{*}{1.000} & \multirow[t]{2}{*}{0.317} \\
\hline & Positive & 2.50 & 1 & 2.50 & & \\
\hline \multirow{4}{*}{$\begin{array}{l}\text { I can sit in peace and } \\
\text { relaxation } \\
\text { I feel lazy or slowed down }\end{array}$} & Negative & 12.50 & 4 & 3.13 & \multirow[t]{2}{*}{1.414} & \multirow[t]{2}{*}{0.157} \\
\hline & Positive & 2.50 & 1 & 2.50 & & \\
\hline & Negative & 13.00 & 4 & 3.25 & \multirow[t]{2}{*}{0.541} & \multirow[t]{2}{*}{0.589} \\
\hline & Positive & 8.00 & 2 & 4.00 & & \\
\hline \multirow{2}{*}{$\begin{array}{l}\text { I feel fear, as if something } \\
\text { is in my stomach }\end{array}$} & Negative & 5.00 & 2 & 2.50 & \multirow[t]{2}{*}{0.000} & \multirow[t]{2}{*}{1.000} \\
\hline & Positive & 5.00 & 2 & 2.50 & & \\
\hline \multirow{2}{*}{$\begin{array}{l}\text { I lost interest in my } \\
\text { appearance }\end{array}$} & Negative & 7.50 & 3 & 2.50 & \multirow[t]{2}{*}{1.000} & \multirow[t]{2}{*}{0.317} \\
\hline & Positive & 2.50 & 1 & 2.50 & & \\
\hline I feel anxious and & Negative & 9.00 & 3 & 3.00 & \multirow[t]{2}{*}{0.447} & \multirow[t]{2}{*}{0.655} \\
\hline $\begin{array}{l}\text { uncomfortable as if there } \\
\text { is something I have to do }\end{array}$ & Positive & 6.00 & 2 & 3.00 & & \\
\hline \multirow{2}{*}{$\begin{array}{l}\text { I am looking to enjoy the } \\
\text { things }\end{array}$} & Negative & 15.00 & 5 & 3.00 & \multirow[t]{2}{*}{2.060} & $* 0.039$ \\
\hline & Positive & 0.00 & 0 & 0.00 & & \\
\hline I suddenly feel anxious & Negative & 21.00 & 6 & 3.50 & 2.333 & $* 0.020$ \\
\hline & Positive & 0.00 & 0 & 0.00 & & \\
\hline I can enjoy a program or & Negative & 8.00 & 3 & 2.67 & 1.134 & 0.257 \\
\hline $\begin{array}{l}\text { topic on the radio or } \\
\text { television or in a book }\end{array}$ & Positive & 2.00 & 1 & 2.00 & & \\
\hline Total of mental health & Negative & 39.00 & 7 & 5.57 & 1.959 & $* 0.050$ \\
\hline & Positive & 6.00 & 2 & 3.00 & & \\
\hline
\end{tabular}

Table No. (15) indicates the results of the Wilcoxon test between the pre and post measurements, mental health indicators. By reviewing the values of significance levels and comparing them with the value 0.05 , it becomes evident that the value of the calculated significance level of mental health is represented by the paragraph (I look forward to enjoying things) and Paragraph No. (I have a sudden feeling of anxiety) in addition to the overall score representing the patient's mental health in general, which amounted to (0.050), which was less (or equal) than 0.05 , as these values reached $(0.039),(0.020)$ and $(0.050)$, which means that there are statistically significant differences between the pre and post measurements in this variable whereas, the significance of the difference was in favor of the post measurement, which has the better arithmetic mean, which represents the average values of the mental health averages in the two points referred to, in addition to the mental health as a whole (You can use the previous arithmetic averages table No. 14) while the values of the significance level for the rest of the points expressing mental health were greater than 0.05 , indicating their lack of statistical significance for the differences between the pre and post measures.

Display the results of the fourth variable (muscle strength)

There are statistically significant differences at $\alpha=0.05$ between the medians of the pre and post measures in favor of the post measures on muscle strength. 
Table 16: averages of muscle strength tests in the pre and post measurements

$\begin{array}{lll}\text { Muscle strength tests N Pre-measurement Post - measurement } & \text { N }\end{array}$

$\begin{array}{llllll} & & \begin{array}{l}\text { Arithmetic } \\ \text { average }\end{array} & \begin{array}{l}\text { Standard } \\ \text { deviation }\end{array} & \begin{array}{l}\text { Arithmetic } \\ \text { average }\end{array} & \begin{array}{l}\text { Arithmetic } \\ \text { average }\end{array} \\ \text { Right grip strength } & 9 & 21.10 & 8.39 & 24.93 & 7.16 \\ \text { Left grip strength } & 9 & 19.06 & 6.48 & 22.36 & 6.70 \\ \text { Lower segment strength } & 9 & 18.33 & 22.12 & 44.67 & 29.90 \\ \text { Upper segment strength } & 9 & 7.00 & 5.85 & 29.44 & 10.91\end{array}$

Table 17: Wilcoxon test results between the pre and post measurements in tests

\begin{tabular}{|c|c|c|c|c|c|c|}
\hline $\begin{array}{l}\text { Muscle strength } \\
\text { indicators }\end{array}$ & $\begin{array}{l}\text { Rank } \\
\text { indication }\end{array}$ & $\begin{array}{l}\text { Total } \\
\text { ranks }\end{array}$ & $\begin{array}{l}\text { The } \\
\text { number of } \\
\text { ranks }\end{array}$ & Average ranks & $\mathrm{Z}$ value & Indication level \\
\hline \multirow{4}{*}{$\begin{array}{l}\text { Right grip strength } \\
\text { (kg) } \\
\text { Left grip strength (kg) }\end{array}$} & Negative & 6.00 & 1 & 6.00 & \multirow[t]{2}{*}{1.958} & \multirow[t]{2}{*}{0.050} \\
\hline & Positive & 39.00 & 8 & 4.88 & & \\
\hline & Negative & 0.00 & 0 & 0.00 & \multirow[t]{2}{*}{2.666} & \multirow[t]{2}{*}{0.008} \\
\hline & Positive & 45.00 & 9 & 5.00 & & \\
\hline Lower Limb Muscle & Negative & 0.00 & 0 & 0.00 & \multirow[t]{2}{*}{2.670} & \multirow[t]{2}{*}{0.008} \\
\hline Strength (V) & Positive & 45.00 & 9 & 5.00 & & \\
\hline Core muscle strength & Negative & 0.00 & 0 & 0.00 & \multirow[t]{2}{*}{2.675} & \multirow[t]{2}{*}{0.007} \\
\hline (V) & Positive & 45.00 & 9 & 5.00 & & \\
\hline
\end{tabular}

Table No. (17) indicates the Wilcoxon test results between the pre and post measurements of muscle strength tests. By reviewing the significance levels values of these tests and comparing them with the value 0.05 , and it turns out that the value of the calculated significance level was less (or equal) than 0.05 , as these values reached $(0.050)$ for the strength of the right hand grip and amounted to $(0.008)$ for the strength of the left hand grip and reached (0.008) for the strength of the muscles of the lower extremities and amounted to (0.007) for the strength of the core muscles, which means that there are statistically significant differences between the pre and post measurements in these tests, so that the significance of the difference was in favor of the post measurement with the better arithmetic mean in which the average values of the averages express the improvement of the average values of strength (you can refer to the previous arithmetic averages table No. 16).

\section{Results discussion}

Discussion of the hypothesis that states: There are statistically significant differences at the level of $\alpha$ $=0.05$ between the mean of the pre and post measurements in favor of the post measures on the variable of pain, quality of life, mental health, muscle strength.

First: pain

After verifying this hypothesis and testing it through the nonparametric Wilcoxon test and through the previous tables, we note that the results indicate the presence of statistically significant differences in four different types of pain according to the scale used, which are pain like stabbing, a feeling of heavy pain, tearing or cutting pain, sickness or disgusting pain, and the absence of statistical significance for the rest of the types. The researcher attributes these results to the nature of fibromyalgia disease, which does not cause all types of pain mentioned in the scale and the improvement of these types is precisely due to the presence of these pains in the patients before the proposed program. This result is in agreement with the study by Scaturro, et al. (2019). However, improvement may occur for some but not all measures of pain.

The results also indicate that there are statistically significant differences in the pain intensity scale as a whole, which means that the proposed program has reduced the percentage of patients experiencing pain in the study sample after undergoing the proposed program, and the researcher attributes these results to the nature of the program's composition and its containment of various exercises such as breathing exercises, strength and stretching of muscles, and aerobic exercises. Which, in turn, alleviate the pain felt by these patients, as exercises work to increase the flexibility of the muscles as a result of the increase in fluid in them and thus improve their ability to contract and relax. And it also increases the ability to relax and the disappearance of spasms and 
muscle stiffness, also, exercise increases the secretion of endorphins, which reduces the patient's sense of pain, and these results are consistent with the results of (Tomas-Carus, et al., 2019), (Oliver, et al., 2019), (Sieczkowska, et al. 2019) and (Andrade, et al., 2018), the results also indicated that there were no differences in the variable best description of pain and the variable period of pain perception, where the researcher attributes these results to the nature of the fibromyalgia disease that comes at intervals and attacks that may be unjustified in some cases in the affected people and therefore it is difficult to obtain a significant difference, especially in the variable period of pain perception, because this period varies from time to time and from person to person depending on his health, psychological and social conditions in that period.

\section{Second: the quality of life.}

After verifying the hypothesis and testing it through Wilcoxon's nonparametric test, the previous tables show that there are no statistically significant differences in the amount of difficulty in the quality of life measure except for a difference in the level of pain when pressing or touch, which was the level of significance at which indicates the existence of a statistical indication, and this is a result consistent with the result of the first hypothesis that the proposed program has reduced pain in patients, as for the absence of differences in the rest of the difficulties, this result differs with the study of Assumpcao, et al. (2017), Andrade, et al. (2018), Sieczkowska, et al. (2019) and Scaturro, et al. (2019). As all these studies confirmed that undergoing standardized rehabilitation programs from therapeutic exercises has a clear effect on improving the quality of life for people with the disease, and by looking at the values of all arithmetic averages for measures of quality of life, we find that they all showed improvement in the quality of life, but these results did not show statistical significance through Wilcoxon's test, and the researcher attributes these results to the small size of the sample and its heterogeneity due to the difficulty of having a homogeneous sample of fibromyalgia patients due to the nature of the symptoms of this disease.

\section{Third: Mental health}

After verifying the hypothesis and testing it through Wilcoxon's nonparametric test, the previous tables show that there are statistically significant differences in favor of the post measurement in each of the variables No. 12, which states: "I look forward to enjoying things." That is, the proposed program has improved the mental health of the patients of the study sample. The researcher attributes this improvement to the nature of the formation of the rehabilitation program in terms of its containment of various sports exercises, from muscle stretching, resistance training, aerobic exercises, and respiratory exercises that improve mood and mental health in particular when committed to exercising them frequently, where the secretion of the happiness hormone (serotonin) increases, where it helps to overcome feelings of depression and anxiety and develop a sense of satisfaction in addition to cognitive behavioral therapy that was provided to the patients through group therapy sessions throughout the program implementation period. These results are in agreement with the study of Assumpcao, et al. (2017) in terms of resistance training relieving feelings of depression, and the study of Andrade, et al. (2018) that adherence to exercise for at least twice a week relieves anxiety and Depression, and the study of Sieczkowska, et al. (2019) and Oliver, et al. (2019) that exercise, especially aerobic exercise, improves mental health in patients with fibromyalgia.

\section{Fourth: muscle strength.}

After verifying the hypothesis and testing it through the non-parameter Wilcoxon test, the previous tables show that there are statistically significant differences in favor of the post measurement, as muscle strength improved in both the upper limbs, the trunk and the lower limbs of the study sample patients, the researcher attributes this result to the subjecting of the study sample patients to the proposed program that includes resistance training gradually for a continuous period of three months Which is sufficient to cause a change in muscle tone, where the elasticity of the muscle fibers increases, which leads to an increase in the strength of muscle contraction, in addition to the increase in the size of the muscle due to an increase in the thickness of the muscle fibers also helps in increasing muscle strength. And what increases the efficiency of the muscle also is the increase in the number of capillaries inside it, the activation of the inactive muscle fibers and the increase in nerve activity in them. And the practice of stretching exercises also helps in treating muscle spasms and improving their flexibility, so that they are able to contract and fully extend, and thus produce greater strength, and this result is consistent with the study of Andrade, et al. (2018) that strength training is of great benefit to patients with fibromyalgia due to the presence of muscle weakness in them as a primary symptom of this syndrome. 


\section{Conclusions}

In light of the above results, the researcher concluded the following:

The commitment of patients with fibromyalgia to practice the proposed standardized program that includes different types of exercises such as breathing and stretching exercises, resistance training and aerobic exercises have an effect in relieving pain in patients.

- $\quad$ The proposed rehabilitation program consisting of physical therapy and cognitive behavioral therapy has an effect on improving the psychological state of fibromyalgia patients.

- $\quad$ Resistance training can be practiced regularly and gradually, as in the suggested program for fibromyalgia patients, and this increases the strength of their muscles.

\section{Recommendations}

In light of the aforementioned conclusions, the researcher recommends the following:

- $\quad$ Fibromyalgia patients have to practice regular and various therapeutic exercises, as in the (proposed program), and make it a way of life in order to relieve them of the pain resulting from this syndrome.

- $\quad$ Conducting a subsequent study and applying the proposed program to a larger sample of patients in order to ensure its impact on their quality of life.

- $\quad$ Fibromyalgia patients should not underestimate the importance of group cognitive behavioural therapy in addition to physical exercises, and they should adhere to it in order to get rid of anxiety and depression and improve the general mood.

to increase their muscle strength.

Fibromyalgia patients should adhere to resistance training as in the suggested program in order

\section{References}

Abu-Dahab, S., AbuRuz, S. M., Mustafa, K., \& Sarhan, Y. (2014). Validation of the Arabic version of the revised Fibromyalgia Impact Questionnaire (FIQR A) on Jordanian females with fibromyalgia. Clinical rheumatology, 33(3), 391-396.

Andrade, A., Steffens, R. D. A. K., Sieczkowska, S. M., Tartaruga, L. A. P., \& Vilarino, G. T. (2018). A systematic review of the effects of strength training in patients with fibromyalgia: clinical outcomes and design considerations. Advances in Rheumatology, 58(1), 36.

Assumpção, A., Matsutani, L. A., Yuan, S. L., Santo, A. S., Sauer, J., Mango, P., \& Marques, A. P. (2017). Muscle stretching exercises and resistance training in fibromyalgia: which is better? A three-arm randomized controlled trial. European journal of physical and rehabilitation medicine.

Bartels, E. M., Dreyer, L., Jacobsen, S., Jespersen, A., Bliddal, H., \& Danneskiold-Samsøe, B. (2009). Fibromyalgia, diagnosis and prevalence. Are gender differences explainable. Ugeskrift for laeger, 171(49), 3588-3592.

Häuser, W., Bernardy, K., Arnold, B., Offenbächer, M., \& Schiltenwolf, M. (2009). Efficacy of multicomponent treatment in fibromyalgia syndrome: A meta-analysis of randomized controlled clinical trials. Arthritis Care \& Research, 61(2), 216-224.

Hawkins, R. A. (2013). Fibromyalgia: a clinical update. The Journal of the American Osteopathic Association, 113(9), 680-689.

Knudson, D., \& Johnston, D. (1995). Validity and reliability of a bench trunk-curl test of abdominal endurance. The Journal of Strength \& Conditioning Research, 9(3), 165-169.

Malasi, T. H., Mirza, I. A., \& El-Islam, M. F. (1991). Validation of the hospital anxiety and depression scale in Arab patients. Acta psychiatrica scandinavica, 84(4), 323-326.

Mathiowetz, V., Weber, K., Volland, G., \& Kashman, N. (1984). Reliability and validity of grip and pinch strength evaluations. The Journal of hand surgery, 9(2), 222-226.

Ollevier, A., Vanneuville, I., Carron, P., Baetens, T., Goderis, T., Gabriel, L., \& Van de Velde, D. (2019). A 12week multicomponent therapy in fibromyalgia improves health but not in concomitant moderate depression, an exploratory pilot study. Disability and rehabilitation, 1-8.

Salazar, A. P., Stein, C., Marchese, R. R., Plentz, R. D., \& Pagnussat, A. S. (2017). Electric Stimulation for Pain Relief in Patients with Fibromyalgia: A Systematic Review and Meta-analysis of Randomized Controlled Trials.

Scaturro, D., Guggino, G., Tumminelli, L. G., Ciccia, F., \& Letizia, G. M. (2019). An intense physical rehabilitation programme determines pain relief and improves the global quality of life in patients with fibromyalgia. Clinical and experimental rheumatology, 37(4), 670-675.

Sieczkowska, S. M., Vilarino, G. T., de Souza, L. C., \& Andrade, A. (2019). Does physical exercise improve quality of life in patients with fibromyalgia?. Irish Journal of Medical Science (1971-), 1-7. 
Terkawi, A. S., Tsang, S., Abolkhair, A., Alsharif, M., Alswiti, M., Alsadoun, A., ... \& Altirkawi, K. A. (2017). Development and validation of Arabic version of the short-form Mcgill pain questionnaire. Saudi journal of anaesthesia, 11(Suppl 1), S2.

Tomas-Carus, P., Garrido, M., Branco, J. C., Castaño, M. Y., Gómez, M. Á., \& Biehl-Printes, C. (2019). Nonsupervised breathing exercise regimen in women with fibromyalgia: A quasi-experimental exploratory study. Complementary therapies in clinical practice, 35, 170-176.

Williams, D. A. (2003). Psychological and behavioural therapies in fibromyalgia and related syndromes. Best practice \& research clinical Rheumatology, 17(4), 649-665. 